IZA DP No. 7795

Public-Private Entanglement: Entrepreneurship in a Hybrid Political Order, the Case of Lebanon

Nora Stel

Wim Naudé

December 2013 


\title{
Public-Private Entanglement: Entrepreneurship in a Hybrid Political Order, the Case of Lebanon
}

\author{
Nora Stel \\ Maastricht School of Management, \\ CCS, University of Utrecht and IFI, American University of Beirut \\ Wim Naudé \\ Maastricht School of Management, University of Maastricht, \\ UNU-MERIT and IZA
}

\section{Discussion Paper No. 7795 December 2013}

\author{
IZA \\ P.O. Box 7240 \\ 53072 Bonn \\ Germany \\ Phone: +49-228-3894-0 \\ Fax: +49-228-3894-180 \\ E-mail: iza@iza.org
}

\begin{abstract}
Any opinions expressed here are those of the author(s) and not those of IZA. Research published in this series may include views on policy, but the institute itself takes no institutional policy positions. The IZA research network is committed to the IZA Guiding Principles of Research Integrity.

The Institute for the Study of Labor (IZA) in Bonn is a local and virtual international research center and a place of communication between science, politics and business. IZA is an independent nonprofit organization supported by Deutsche Post Foundation. The center is associated with the University of Bonn and offers a stimulating research environment through its international network, workshops and conferences, data service, project support, research visits and doctoral program. IZA engages in (i) original and internationally competitive research in all fields of labor economics, (ii) development of policy concepts, and (iii) dissemination of research results and concepts to the interested public.
\end{abstract}

IZA Discussion Papers often represent preliminary work and are circulated to encourage discussion. Citation of such a paper should account for its provisional character. A revised version may be available directly from the author. 
IZA Discussion Paper No. 7795

December 2013

\section{ABSTRACT}

\section{Public-Private Entanglement: Entrepreneurship in a Hybrid Political Order, the Case of Lebanon}

The instability and informality that characterize hybrid political orders and its effects on entrepreneurs remains largely unexplored in the scholarly literatures. In this paper we provide initial findings from the case of entrepreneurs' access to electricity in Lebanon. Using quantitative and qualitative methods we find that political connections significantly influence the investment decisions of entrepreneurs and the performance of their firms. In general, a hybrid political order imposes a 'tax' on entrepreneurship by channelling entrepreneurial talent into lobbying and bribery; by reinforcing male and family-owned dominance in business; and by skewing investment decisions. Specifically, we find that family firms whose entrepreneurs engage in bribery, and who obtain government contracts alleviate electricity problems and perform better.

JEL Classification: L26, M48, O17, O53

Keywords: entrepreneurship, development, political economy, electricity, infrastructure, Middle East, Lebanon, hybrid political order

Corresponding author:

Wim Naudé

Maastricht School of Management

P.O. Box 616

6200 MD Maastricht

The Netherlands

E-mail: naude@msm.nl 


\section{Public-Private Entanglement: Entrepreneurship in a Hybrid Political Order, the Case of Lebanon}

\section{Introduction}

Entrepreneurial decision-making and firm performance are influenced by the institutional context within which entrepreneurs function (Naudé, 2010a; 2010b). One important dimension of any country's institutional context is its political order, specifically the extent to which it can be considered hybrid and whether it is an open or limited access order (Boege et al., 2009; North et al., 2007; 2009). While hybrid and limited access orders are argued to be detrimental for the development of entrepreneurship, there remains a gap in our empirical understanding of how political hybridity and limited access de facto impact on entrepreneurial decisionmaking and firm performance (Brück et al., 2013; Kenyon and Naoi, 2010; Stel, 2013). In this paper we provide initial findings on how entrepreneurial decisions and resultant firm performance are affected in a hybrid political order by studying the case of entrepreneurs' access to electricity in Lebanon.

We focus on entrepreneurs' access to electricity because it offers a potentially useful angle from which to obtain a better understanding of how a hybrid political order shapes entrepreneurial performances and decisions. Problems with electricity supply are often cited as the most serious obstacle to doing business faced by entrepreneurs across the world (Alby et al., 2013). High and unreliable electricity delays production, raises prices, impacts negatively on firms' reputations and makes the provision of certain goods and services uncompetitive. How such constraints affect entrepreneurs' performance and decision-making will depend on the nature of the political order they operate in. In an open access order, for instance, entrepreneurs may use elections and political watchdog organizations to (indirectly) apply pressure on elected politicians to invest public resources in electricity provision and ensure fair and reliable access. In limited access orders, by contrast, it is entrepreneurs' and firms' direct 
access to the ruling elite and its patronage system that may determine the quantity and quality of the electricity they can obtain.

In such limited access, hybrid political orders, entrepreneurs who are excluded may be permanently shackled by lack of access to electricity, resulting in their firms' sub-optimal performance and skewing their investment decisions. But since entrepreneurs are almost by definition individuals who overcome obstacles to create and manage firms (Leibenstein, 1968), we should expect entrepreneurs in hybrid political regimes to employ various strategies to overcome their lack of access to electricity. The literature suggests they may, for instance, revert to lobbying, bribing, using family connections and networks, and/or by-passing central government altogether and access (private) local substitutes such as investing in their own electricity generators (Alby et al, 2013; Reinikka and Svensson, 2002).

Lebanon offers an interesting case to test some of the above speculations, as it is a key example of a hybrid political order (see section 4.1.), it is renowned for its entrepreneurial acumen (Ahmad and Julian 2012) and high utility (electricity) costs have been identified as one of the main constraints facing entrepreneurs (Stel, 2013; World Bank, 2008; Dagher and Yacoubian, 2012; Kanaan, 2011).

The remainder of the paper is structured as follows. First, in section 2 we provide an overview of the relevant literature and propose three hypotheses linking electricity problems as a feature of hybrid political orders with entrepreneurial decisions and firm performance. Then, in section 3, we outline our research methodology. The Lebanese case-context is introduced in section 4. The regression results, interpreted through the lenses of our qualitative survey, are presented in section 5 and further analysed and discussed in section 6 . Section 7 concludes. In essence we find that a hybrid political order imposes a significant 'tax' on entrepreneurship through channelling entrepreneurial talent into lobbying and bribery; through reinforcing male and family-owned dominance in business and by skewing investment decisions.

\section{Literature Review and Hypotheses}

There is a large literature on the nature and determinants of firm performance, see for instance Coad et al. (2013), Coad and Tamvada (2012), Dollar et al. (2005) and Sørensen and Chang 
(2006) as well as a growing literature on entrepreneurship in developing countries (Gollin, 2008; Naudé, 2010a, 2013; Quatraro and Vivarelli, 2013). However, in this paper our interest is not on firm performance per se, but rather on how firm performance and entrepreneurial behavior are affected by key features of a hybrid political order. As such we will not survey the literature on firm performance here. It suffices to mention that there are still relatively few firm-level studies of entrepreneurship in developing countries and countries in conflict, and particularly in countries characterized by politically hybrid governance structures such as Lebanon (Brück et al., 2013; Stel, 2013; Guglielmetti, 2010). In this section, therefore, we discuss the salient points in the literature on hybrid political orders, specifically the manifestation of hybridity in access to electricity. We draw from this literature a number of hypotheses on the relationship between such governance elements and entrepreneurship. The relationships between governance, political instability, access to electricity, and informal systems of political influence, whether it is through 'off the record' payments or family connections, will be a central focus.

\subsection{Hybrid Political Orders}

A political order is the sum of institutionalized power relations that one can empirically grasp at a given time and place (Hagmann and Hoehne, 2009:44). In a hybrid political order, political and economic power is divided along 'diverse and competing authority structures, sets of rules, logics of order, and claims to power [that] co-exist, overlap, and intertwine, combining elements of introduced Western models of governance and elements stemming from local indigenous traditions of governance' (Boege et al., 2009:17). ${ }^{1}$ Such political hybridity has two core manifestations. The first is instability, often in the form of vulnerability to conflict or natural disaster (Naudé et al., 2011). Instability, however, also becomes apparent in the fluctuating power of political elites and the resultant deadlock in decision-making and policy implementation (Hasbani, 2011). The second manifestation of hybridity is informality. Informality as a form of hybridity, in the context of access to electricity, ties in with two other

\footnotetext{
${ }^{1}$ The notion of the hybrid political order should not be confused with that of the hybrid regime (Schmotz, 2010; Kenyon and Naoi, 2010). A hybrid political order denotes a broader governance system, whereas a hybrid political regime refers to a more narrow political system on the continuum between democratic and autocratic regimes.
} 
concepts, namely the 'dual game' analogy and the notion of the 'open/limited access order.' The 'dual game' logic (Cammett and Issar, 2010:383) combines an electoral game, in which parties and groups aim to gain votes, with a regime game encompassing the struggle over the basic rules of allocating power in the polity. Power-sharing agreements in the electoral game can then 'act as a fig leaf that obscures important issues' in the regime game (Lund, 2011:51, 58). The regime component of the dual game often prevents a merit-based bureaucracy from emerging, instead generating a public system in which clientelist distribution of jobs is the core function (Briscoe, 2009:16). The intuitive logic of the dual game idea corroborates with institutional overlap between formal state institutions and informal 'traditional' authorities at the heart of the hybrid political order concept. The idea of the limited versus open access order points at the degree to which access to decision-making processes and resources allocated by public institutions is either equal or discriminatory (i.e. dependent on political, economic, ethnic or private networks and connections). In limited access orders, 'political elites divide up control of the economy, each getting some share of the rents' (North et al., 2007: ii).

In essence, the concepts of hybridity, informality, dual game and limited access order all denote issues revolving around an informal overlap between the public and private sectors which results in an oligopolistic organization of society, politics and business. In such a setting, connections, networks and relations constitute a disproportionally important economic resource for entrepreneurs. Such connections are utilized through processes of lobbying, bribery and establishing supply ties to government.

\subsection{Utilities and Electricity in Hybrid Political Orders}

The conceptual relation between political hybridity and the provision of utility services follows from the above introduced notions of oligarchy and limited access orders. In hybrid political orders, access to electricity - for either entrepreneurs or citizens - does not follow predominantly from formal registrations - as businesses or citizens - but rather from informal relations with elite powerbrokers, who often have political as well as economic clout (which is the very essence of the notion of oligarchy) (Foster and Steinbuks, 2009; OECD, 2008; Vaux and Visman, 2005; Bardhan, 2004; Berry et al., 2010). Services such as electricity are then, to a large extent, not a public right, but a political favor. The exact expression of limited access to 
electricity as a result of the oligarchic governance of electricity sectors in entrepreneurs' behavior, however, remains under-researched.

Alby et al. (2013), for instance, using the same World Bank Enterprise Survey (WBES) database that we do, analyzed a sample of 46,606 firms across 87 countries over the period 2002 to 2006. They were particularly interested in the degree to which electricity supply constraints affect enterprise behavior. They found that 15 per cent of all entrepreneurs interviewed indicated that electricity supply is a major or very severe constraint to doing business. They also found that 31 per cent of all firms surveyed across the sample owned or shared an electricity generator, and that generator ownership was highest in regions of the world where the number of annual power outages where highest (Sub-Saharan Africa and South Asia). Alby et al. (2013) estimated the determinants of the decision of a firm to invest in an own electricity generator, finding that it is influenced by the number of power outages, as well as access to financing and a number of standard control variables. They did not ask to what extent political instability, political influence and family networks, and hence the political order of a country, influenced this decision.

\subsection{Hypotheses}

Based on the previous discussions we may reasonably expect that:

H1: Unreliable electricity provision has a negative impact on firm performance in Lebanon.

H2: The negative impact of unreliable electricity provision on firm performance is mediated by the reactions of entrepreneurs to, on the one hand, invest in their own generators (skewed investment) and, on the other, attempt to influence state authorities (public-private entanglement).

\section{Methodology}

We use both qualitative and quantitative methods to explore and test the two hypotheses that we have derived in the previous section. 
Our quantitative data consist of the 2009 WBES of 382 establishments in Lebanon. First, in section 4.2 we present some descriptive statistics on the nature of entrepreneurship and the obstacles faced by firms, including lack of access to electricity, and political uncertainty. Then, in section 5, we present results from two sets of regressions. In the first, we run a simple OLS regression model of two measures of firm performance (sales growth and employment growth) on the effect of electrical power outages and political instability as well as a number of standard control variables. In the second, we run a probit regression model of the discrete decision to use an own generator (or not) as a function of political instability and electrical power outages, as well as a number of standard control variables.

We augment this approach by the results from qualitative interviews with Lebanese entrepreneurship experts that we conducted in Lebanon in the summer of 2012. We use the findings from this qualitative study to better understand the descriptive and regression results. The interviews covered 32 local experts on entrepreneurship and business. Respondents were selected based on preliminary stakeholder mapping and subsequent snow-ball sampling. Considering the lack of previous work on political hybridity and entrepreneurship, and the likely multi-faceted links between business and politics in such circumstances, we accessed a broad and diverse group of experts (from civil society, academia, journalism, the private sector, government and the international donor community) rather than businessmen and entrepreneurs. $^{2}$

\section{Lebanon}

\subsection{Lebanon's Hybrid Political Order}

Lebanese society is organized along the lines of 18 recognized religious communities that each have their regional strongholds; political parties; social institutions; and armed militias. The central concept to understand Lebanese society, then, is sectarianism, which signifies this division of society into religious, 'sectarian,' communities (Faour, 2007; Haddad, 2002). Sectarianism corresponds with the polarization of social control between Lebanon's various

\footnotetext{
${ }^{2}$ See Stel (2012) for a more elaborate description of the qualitative methodology used.
} 
communities. This fractionalization breeds a structural elitism: because society is organized along sectarian lines, citizens have historically depended on sectarian leaders for protection and provision (Ziadeh, 2006).

The Lebanese state is organized through a consociational political system centered on an intersectarian power-sharing formula that stipulates that the President of the Republic should be a Maronite Christian, the Prime Minister a Sunni Muslim and the Speaker of Parliament a Shia Muslim. The system includes corresponding sectarian quota guiding the allocation of all public positions. The resultant quest for inter-communitarian balance results in endemic patronage and clientelism, and a highly oligopolistic market structure (Hamzeh, 2001; Cammett and Issar, 2010). ${ }^{3}$

\subsection{Lebanese Entrepreneurship}

The World Economic Forum (WEF) (2011:9) estimates that 15 per cent of the Lebanese adult population is engaged in entrepreneurial activity, but notes that this is mostly necessity entrepreneurship that revolves around self-employment rather than job generation. The vast majority (96 per cent) of the Lebanese firms surveyed by WBES are in private, domestic ownership. Foreign ownership, on average around 4 per cent of firms, is thus low by international standards: generally in the WBES's foreign ownership is around 10 per cent. None of the firms had government ownership in the formal sense, but the nature of Lebanon's hybrid political order stipulates that even if these firms do not have any formal government ownership, they are subject within the political order to omnipresent political influence.

In three notable aspects Lebanese firms seem different from other Middle Eastern firms. First, they have much more females in top management positions. In 2009, 29 per cent of firms in Lebanon had a female as top manager - compared to 1.2 per cent for the Middle East on average. Second, Lebanese firms surveyed are much older on average: 26 years, compared to 13 years average. Third, Lebanese firms seem technologically much more advanced than their Middle Eastern counterparts. The first two characteristics might partially be explained by the

\footnotetext{
${ }^{3}$ More than 50 per cent of 300 markets are in the hands of a few companies and two per cent of companies take more than 50 per cent of loans (Lebanese Center for Policy Studies (LCPS), 2011).
} 
predominance of family firms in Lebanon, one of the most defining characteristics of the Lebanese economy according to our interviewees. Fahed-Sreih et al. (2010:37) pose that family businesses constitute 85 per cent of the private sector, accounting for 1.05 million of 1.24 million jobs. The familial nature of many businesses may explain the prevalence of female managers in the sense that a family patriarch or history might back of these businesswoman. Family business also are often much longer-lived than non-family businesses.

\subsection{Lebanese Electricity}

The state-owned Electricité du Liban (EDL) is responsible for electricity production, transmission and distribution in Lebanon. It provides around 77 per cent of the country's electricity demand, with private generators providing the remainder (Hasbani, 2011). Power interruptions are typical in Lebanon, and it is not rare to have only four hours of electricity a day (Dagher and Ruble, 2011). The World Bank (2008:4) notes that

\footnotetext{
"the Lebanese electricity sector is at the heart of a deep crisis. The sector is unable to supply the reliable electricity needed by homes, offices and industry. It is a massive drain on government finances, crowding out more valuable expenditures on education, infrastructure, social protection, and health, and putting macroeconomic stability at risk. [...] The state of the electricity sector symbolizes Lebanon's profound challenges of governance and accountability."
}

The WBES data in Figure 1 show that although there are frequent electrical outages in Lebanon, the duration of the outages is on average much shorter than in other Middle Eastern countries. Moreover, Lebanese businesses seem better prepared to operate under these conditions as many more business firms own or share an electricity generator than in other Middle East countries. The poor provision of electricity supply in Lebanon does not seem to be amenable or dependent on a regime of bribery or corruption. Only 9 per cent of Lebanese firms indicated that they may be expected to give a bribe to get an electricity connection, compared to 48 per cent of firms that indicated as much in other Middle Eastern countries on average. 
Figure 1: Electricity as Business Obstacle

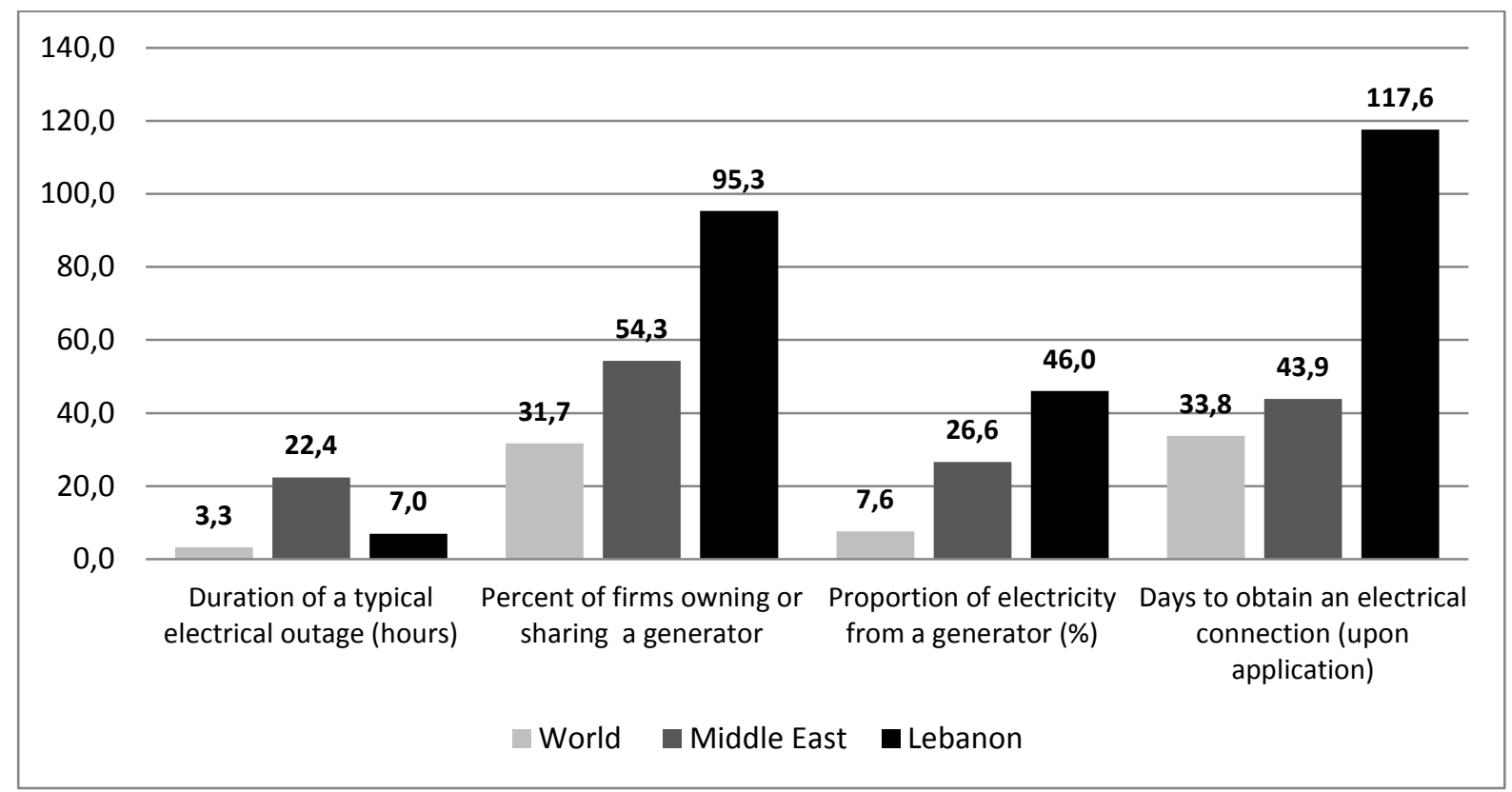

(Source of data: WBES, Lebanon, 2009).

\section{Empirical Findings}

\subsection{Constraints on Lebanese Entrepreneurs}

Given our interest in entrepreneurship within the hybrid political order in Lebanon, we will not deal with all the aspects covered in the WBES; rather we will focus on the issues that most pertinently reflect changes in entrepreneurial behavior that may be a result of the political order. These include in particular the obstacles faced by entrepreneurs, i.e. the dimensions of being entrepreneurial that are most affected by aspects of the hybrid political order in Lebanon, such as corruption, political uncertainty, lobbying, bribery, networks and conflict and insecurity. According to the Lebanese firms surveyed, their greatest single obstacle to doing business is political instability, ${ }^{4}$ a feature established as a key symptom of hybrid political orders in section 2.1. Other major obstacles are access to and reliability of electricity,

\footnotetext{
${ }^{4}$ Political instability is not defined in the WBES: respondents are asked the following, namely to 'Judge its severity as an obstacle on a scale from 0 to 4,0 being "No obstacle" and 4 being "Very severe obstacle". It is thus a subjective evaluation.
} 
corruption and finance. Figure 2 lists the responses of the firms regarding the relative importance of a number of possible obstacles to doing business.

Figure 2: Self-Reported Biggest Obstacle to Business

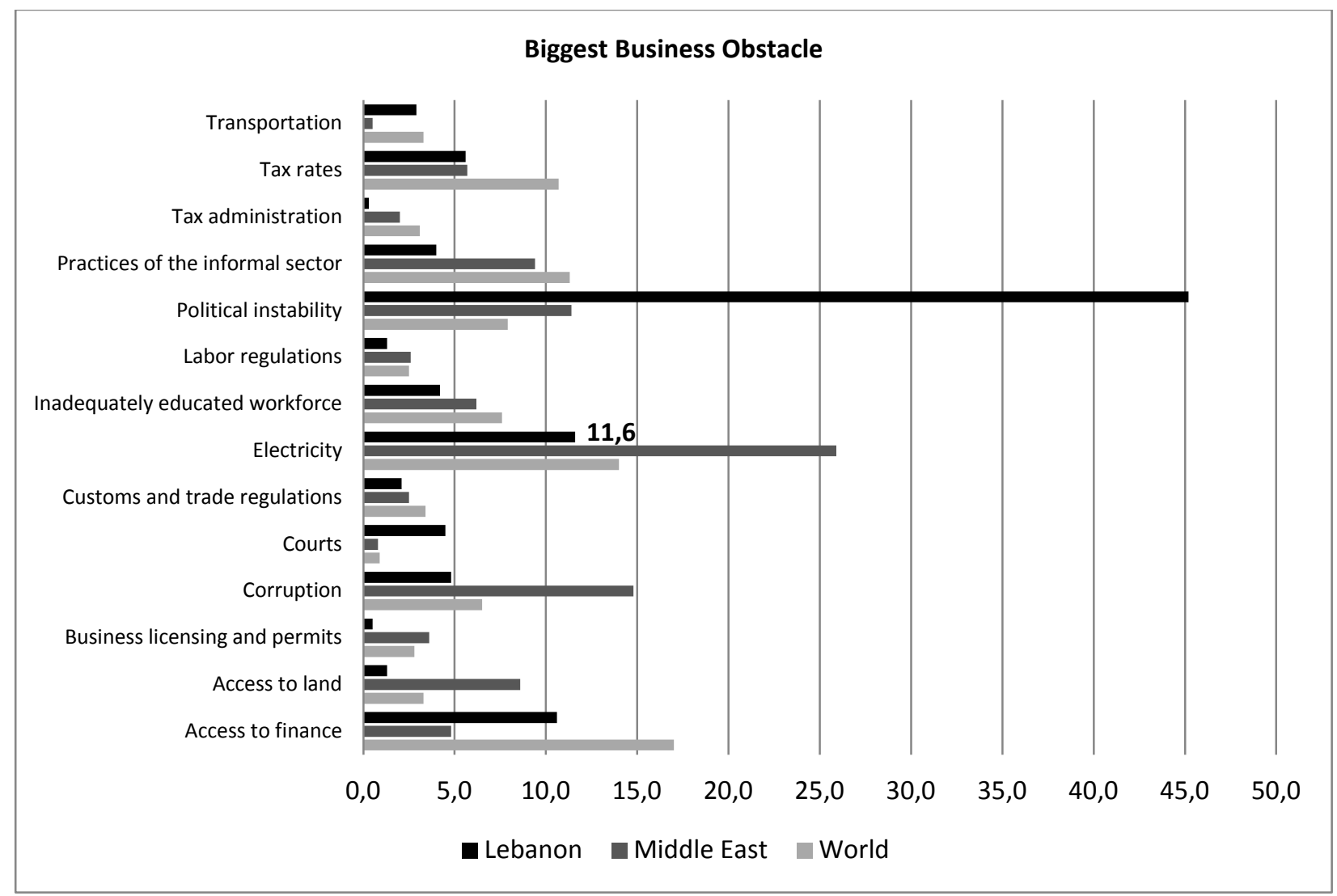

(Source of data: WBES, Lebanon, 2009).

Obstacles are experienced differently by small and medium sized firms on the one hand and larger firms on the other. In Lebanon, political instability seems to be more acutely felt as an obstacle by larger firms (with more than 100 employees) than smaller firms (with less than 20). More than 50 per cent of large firms reported political instability to be the biggest obstacle, compared to 40 per cent of small firms. In contrast, smaller firms more proportionately reported access to finance and electricity as the biggest constraints. ${ }^{5}$

\footnotetext{
${ }^{5}$ We have to stress here that the WBES data is from 2009; our own interviews were conducted in 2012 . In the three-year period in between the electricity period has deteriorated immensely (Hasbani, 2011).
} 
The emphasis on political instability on the one hand and electricity on the other does not mean that bribery (corruption) is not an obstacle to entrepreneurship in Lebanon. As was shown in Figure 2, almost 5 per cent of firms indicated corruption as the worst business obstacle. We already mentioned that larger firms experienced more problems with corruption. One reason for this may be that larger firms tend to be more interested in tendering for government contracts. In Lebanon, 97 per cent of all firms indicated that they would be expected to pay a bribe for getting a government contract (compared to 47 per cent on average in other Middle Eastern countries), and in fact 100 per cent of large firms (those with more than 100 employees) indicated as such. The average value of a bribe is reported to be around 8 per cent of the value of the contract, which makes Lebanese government contracts almost twice as 'expensive' as government contracts on average in the Middle East (see Leenders (2012) for an elaborate dissection of the governmental contracting system). Thus, the issue is not so much individual bribes on the consumption level of the electricity sector; the issue is the corrupt organization of the governance level of the electricity sector that results in higher prices, because bribes for contracts have to be earned back, and oligopolies, because contracts often come with political protection.

\subsection{Regression Results}

We are interested, first, in how a hybrid political order affects firm performance, as measured by sales and employment growth (hypothesis H1). Second, we are interested in how firms respond to electricity constraints generated by a hybrid political order, in particular how hybridity affects decisions of a firm to invest in its own power generator or its relations with political elites (hypothesis H2). Our basic hypothesis is that firm performance is negatively affected by unreliable electricity provision, but that firms who are able to access generators and/or political elites may experience electricity supply and political instability to be less serious business obstacles. Because the establishment of substitutes and the lobbying of government officials take time and effort, we hypothesized that although these will help firms overcome electricity and political instability problems; it will still impact negatively on firm performance, in particular on sales and employment growth (hypothesis 2). 


\subsubsection{Determinants of Firm Performance in Lebanon}

We estimated various OLS regression models with dependent variables variously measuring firm performance as mentioned.

As explanatory variables we have our variables of interest, that include whether firms have indicated political instability and electricity supply to be major or serious obstacles to business; whether a firm has access to a generator; the number of days of power outages suffered; as well as the amount of electricity provided by a generator. Because the mere presence of a generator does not mean a firm can actually use it, we also take into account the extent to which electricity can be obtained from a private generator when there are power outages by creating an interaction term between the number of outages and the share of electricity generated through a private generator. Hence the firms who are able to generate more electricity privately as the number of outages increases may perform better. We also include whether the firm bribed government officials to obtain an electricity connection during the year as a measure of local influence over decision-makers.

In addition to our explanatory variables, we also include a number of control variables. These are standard control variables as found in the empirical literature on firm performance and include measures of firm characteristics (age and size of the firm; innovativeness; and whether it is a family firm), management characteristics (gender of owner and managers' skills), quality of labour (laborers' skills), industry characteristics (sector; networking; and dependence on government) and access to finance (use of bank credit to finance working capital). The variable abbreviations and descriptions are contained in Table 1. 
Table 1: Variable Description

\begin{tabular}{|c|c|c|}
\hline Variable & Description & $\begin{array}{l}\text { Question } \\
\text { number }\end{array}$ \\
\hline \multicolumn{3}{|l|}{ Dependent } \\
\hline Sales & \% change is firms' sales in 2008-2009 year. & \\
\hline Employ & Average annual employment growth from 2006-2008. & \\
\hline \multicolumn{3}{|l|}{ Independent } \\
\hline Political & $\begin{array}{l}\text { A binary variable }=1 \text { if political instability is a major or very severe obstacle to the } \\
\text { firm; if otherwise }=0 .\end{array}$ & \\
\hline Electricity & $\begin{array}{l}\text { A binary variable = } 1 \text { if lack of electricity is a major or very severe obstacle to the firm; } \\
\text { if otherwise }=0 .\end{array}$ & \\
\hline Outages & $\begin{array}{l}\text { The numbers of times the previous year that power service interruptions were } \\
\text { experienced. }\end{array}$ & \\
\hline Out*Gen & $\begin{array}{l}\text { A constructed variable obtained from the number of times the previous year that } \\
\text { power service interruptions were experienced, multiplied with the } \% \text { of electricity } \\
\text { used provided by an own generator. }\end{array}$ & \\
\hline Bribes & The amount that the firm spent on bribes as a \% of annual sales in 2009. & \\
\hline \multicolumn{3}{|l|}{ Controls } \\
\hline Age & The age of the firm in years since establishment. & \\
\hline Smallfirm & $\begin{array}{l}\text { A binary variable }=1 \text { if the firm is a small firm in terms of employment; = } 0 \text { if } \\
\text { otherwise. }\end{array}$ & \\
\hline Female & A binary variable $=1$ if the owner of the firm is female; if male $=0$ & \\
\hline Family & A binary variable $=1$ if the firm is a family firm; if otherwise $=0$. & \\
\hline Innovate & $\begin{array}{l}\text { A binary variable }=1 \text { if the firm introduced a new product or service in the past year; } \\
\text { if not }=0 \text {. }\end{array}$ & \\
\hline Sector & $\begin{array}{l}\text { Three binary variable respectively }=1 \text { if the firm is in manufacturing, trade or } \\
\text { services, and }=0 \text { if otherwise. }\end{array}$ & \\
\hline Network & A binary variable $=1$ if the firm belongs to a business chamber; if not $=0$ & \\
\hline $\begin{array}{l}\text { Sales to } \\
\text { Government }\end{array}$ & $\begin{array}{l}\text { The \% of a firm's domestic sales in } 2008 \text { to the government and state-owned } \\
\text { enterprises. }\end{array}$ & \\
\hline Skills Manager & $\begin{array}{l}\text { A binary variable }=1 \text { if the senior manager has graduate education or higher; = } 0 \text { if } \\
\text { otherwise. }\end{array}$ & \\
\hline Skills Labour & The \% of the firm's laborers with university degree. & \\
\hline Finance & The \% of a firm's inputs bought on credit. & \\
\hline
\end{tabular}

The results of the regression analyses are contained in the following three tables, each reporting respectively on the regressions with sales growth, employment growth and capacity utilization as dependent variables. 
Table 2: Impact of Political Hybridity on Sales Growth Performance of Lebanese Firms, 2008

\begin{tabular}{|c|c|c|c|c|}
\hline Variable & Model 1 & Model 2 & Model 3 & Model 4 \\
\hline Constant & $\begin{array}{l}96.095 \\
(2.52)^{*}\end{array}$ & $\begin{array}{l}-13.789 \\
(-0.58)\end{array}$ & $\begin{array}{l}-280.374 \\
(-2.10)^{*}\end{array}$ & $\begin{array}{l}-258.326 \\
(-2.05)\end{array}$ \\
\hline \multicolumn{5}{|l|}{ Independent } \\
\hline Political & $\begin{array}{l}-70.876 \\
(-2.17)^{*}\end{array}$ & $\begin{array}{l}20.679 \\
(1.09)\end{array}$ & $\begin{array}{l}100.412 \\
(2.36)\end{array}$ & $\begin{array}{l}67.929 \\
(1.46)\end{array}$ \\
\hline Electricity & $\begin{array}{l}-49.146 \\
(-1.77)^{*}\end{array}$ & $\begin{array}{l}22.87 \\
(1.11)\end{array}$ & $\begin{array}{l}35.998 \\
(1.36)\end{array}$ & $\begin{array}{l}75.016 \\
(1.96)\end{array}$ \\
\hline Out*Gen & $\begin{array}{l}.00258 \\
(2.13)^{*}\end{array}$ & $\begin{array}{l}.00074 \\
(1.14)\end{array}$ & $\begin{array}{l}.0018 \\
(1.64)\end{array}$ & $\begin{array}{l}.001 \\
(0.88)\end{array}$ \\
\hline Bribes & & $\begin{array}{l}-3.844 \\
(-2.56)^{*}\end{array}$ & $\begin{array}{l}-6.213 \\
(-2.80)^{*}\end{array}$ & $\begin{array}{l}-3.022 \\
(-0.95)\end{array}$ \\
\hline \multicolumn{5}{|l|}{ Controls } \\
\hline Age & & & $\begin{array}{l}.845 \\
(0.84)\end{array}$ & $\begin{array}{l}1.306 \\
(1.31)\end{array}$ \\
\hline Smallfirm & & & $\begin{array}{l}18.42 \\
(0.46)\end{array}$ & $\begin{array}{l}12.63 \\
(0.33)\end{array}$ \\
\hline Female & & & $\begin{array}{l}33.92 \\
(1.04)\end{array}$ & $\begin{array}{l}62.13 \\
(1.68)\end{array}$ \\
\hline Innovate & & & $\begin{array}{l}47.156 \\
(1.49)\end{array}$ & $\begin{array}{l}40.809 \\
(1.37)\end{array}$ \\
\hline Sector: Man & & & $\begin{array}{l}102.83 \\
(1.00)\end{array}$ & $\begin{array}{l}97.33 \\
(1.02)\end{array}$ \\
\hline Sector: Trade & & & $\begin{array}{l}137.638 \\
(1.43)\end{array}$ & $\begin{array}{l}160.788 \\
(1.76)\end{array}$ \\
\hline Sector: Services & & & $\begin{array}{l}116.894 \\
(1.09)\end{array}$ & $\begin{array}{l}102.477 \\
(1.02)\end{array}$ \\
\hline Network & & & $\begin{array}{l}51.370 \\
(0.92)\end{array}$ & $\begin{array}{l}72.269 \\
(1.33)\end{array}$ \\
\hline Skills Manager & & & $\begin{array}{l}2.139 \\
(0.04)\end{array}$ & $\begin{array}{l}.848 \\
(0.02)\end{array}$ \\
\hline Skills Labour & & & $\begin{array}{l}-.725 \\
(-1.09)\end{array}$ & $\begin{array}{l}-.598 \\
(-0.96)\end{array}$ \\
\hline Finance & & & $\begin{array}{l}-.609 \\
(-1.26)\end{array}$ & $\begin{array}{l}-.7346 \\
(-1.59)\end{array}$ \\
\hline Sales to Government & & & $\begin{array}{l}1.701 \\
(2.34)^{*}\end{array}$ & $\begin{array}{l}1.536 \\
(2.23)^{*}\end{array}$ \\
\hline Family & & & & $\begin{array}{l}-69.108 \\
(-1.33)\end{array}$ \\
\hline Diagnostics & & & & \\
\hline $\mathrm{N}$ & 165 & 28 & 22 & 22 \\
\hline $\mathrm{F}$ & $3.61 *$ & $2.62 *$ & 1.25 & 1.46 \\
\hline Adj. $R^{2}$ & 0.05 & 0.19 & 0.16 & 0.27 \\
\hline
\end{tabular}

(t-values are in brackets. An asterisk indicates significance at the $10 \%$ level, ${ }^{* *}$ at the $5 \%$ level and ${ }^{* * *}$ at the 1\% level) 
Table 3: Impact of Political Hybridity on Employment Growth Performance of Lebanese Firms, 2008

\begin{tabular}{|c|c|c|c|c|}
\hline Variable & Model 1 & Model 2 & Model 3 & Model 4 \\
\hline \multirow[t]{2}{*}{ Constant } & 12.553 & 3.773 & 1.0129 & -2.7463 \\
\hline & $(1.84)^{*}$ & $(0.67)$ & $(0.06)$ & $(-0.16$ \\
\hline \multicolumn{5}{|l|}{ Independent } \\
\hline \multirow[t]{2}{*}{ Political } & -9.783 & -2.209 & 2.294 & 4.569 \\
\hline & $(-1.69)^{*}$ & $(-0.49)$ & $(0.28)$ & $(0.54)$ \\
\hline \multirow[t]{2}{*}{ Electricity } & 4.313 & 3.505 & 4.370 & 2.887 \\
\hline & $(0.93)$ & $(0.87)$ & $(0.83)$ & $(0.52)$ \\
\hline \multirow[t]{2}{*}{ Out*Gen } & -.000 & -.000 & -.000 & -.000 \\
\hline & $(-0.41)$ & $(-0.40)$ & $(-0.33)$ & $(-0.12)$ \\
\hline \multicolumn{5}{|l|}{ Bribes } \\
\hline \multicolumn{5}{|l|}{ Controls } \\
\hline \multirow[t]{2}{*}{ Age } & & & .1010 & .0892 \\
\hline & & & $(0.73)$ & $(0.64)$ \\
\hline \multirow[t]{2}{*}{ Smallfirm } & & & -9.272 & -8.5850 \\
\hline & & & $(-1.87)^{*}$ & $(-1.70)$ \\
\hline \multirow[t]{2}{*}{ Gender } & & & -1.2528 & -1.996 \\
\hline & & & $(-0.27)$ & $(-0.42)$ \\
\hline \multirow[t]{2}{*}{ Innovate } & & & 2.2334 & 2.6815 \\
\hline & & & $(0.53)$ & $(0.64)$ \\
\hline \multirow[t]{2}{*}{ Sector: Man } & & & -3.648 & -4.938 \\
\hline & & & $(-0.47)$ & $(-0.62)$ \\
\hline \multirow[t]{2}{*}{ Sector: Trade } & & & 1.482 & 1.3217 \\
\hline & & & (0.19) & $(0.17)$ \\
\hline \multirow[t]{2}{*}{ Sector: Services } & & & -1.813 & -1.997 \\
\hline & & & $(-0.24)$ & $(-0.26)$ \\
\hline \multirow[t]{2}{*}{ Network } & & & -3.9607 & -4.898 \\
\hline & & & $(-0.45)$ & $(-0.55)$ \\
\hline \multirow[t]{2}{*}{ Skills Manager } & & & 3.8351 & 4.3709 \\
\hline & & & $(0.44)$ & $(0.50)$ \\
\hline \multirow[t]{2}{*}{ Skills Labour } & & & -.0023 & .0024 \\
\hline & & & $(-0.03)$ & $(0.03)$ \\
\hline \multirow[t]{2}{*}{ Finance } & & & .02261 & .0377 \\
\hline & & & $(0.39)$ & $(0.62)$ \\
\hline \multirow[t]{2}{*}{ Sales to Government } & & & .02085 & .03286 \\
\hline & & & (0.19) & $(0.30)$ \\
\hline \multirow[t]{2}{*}{ Family } & & & & 4.553 \\
\hline & & & & $(0.90)$ \\
\hline
\end{tabular}

\begin{tabular}{lcccc}
\hline Diagnostics & & \\
$\mathrm{N}$ & 310 & 50 & 43 & 43 \\
$\mathrm{~F}$ & 1.19 & 0.41 & 0.55 & 0.57 \\
Adj. $\mathrm{R}^{2}$ & 0.00 & -0.04 & -0.20 & -0.21 \\
\hline \multicolumn{2}{l}{ (t-values are in brackets. An asterisk indicates significance at the $10 \%$ level, ${ }^{* *}$ at the $5 \%$ level and ${ }^{* * *}$ at the $1 \%$ level) }
\end{tabular}


Table 2 contains the regression results on the determinants of sales growth of firms over the period 2008 to 2009, expressed in local currency units. Table 3 reports on the determinants of employment growth, expressed in number of permanent employees. Four models have been estimated in each case, the results reported in columns 2 to 5 of the two tables.

Model 1 is a simple regression of the measure of performance on the basic variables of interest, namely the degree to which electricity problems and political instability have been reported as a major and/or serious constraint, and the extent to which a firm is able to generate its own electricity in case of (an increase in) power outages. In case of Table 2 (sales growth) all coefficients in model 1 are of the expected sign and statistically significant. Hence we can confirm that, ceteris paribus, firms who reported political instability and electricity problems as major and serious obstacles also experienced significantly lower sales growth during the year. However, table 3 shows that only those firms who reported political instability as a major or serious obstacle had a decrease in employment, and that electricity supply problems does not seem to impact on employment growth. Furthermore, from Table 2 it seems that firms who had better access and use of an own, or shared power generator, were able to achieve higher sales growth.

In Model 2 we added as explanatory variable the amount that a firm spent during the year on bribes ('informal payments') to government officials to get business done. It can be seen that once we control for the ability and extent of firms to engage in such payments, the extent to which firms report political instability and electricity problems ceases to have a statistical significant impact on sales growth (Table 2) and also that where political instability was reported as a problem it ceases to impact significantly on employment growth (Table 3). Paying bribes however, is associated with significantly lower sales growth, indicating that while bribes may address access to electricity, it reflects the broader limited access order that depresses firm performance.

In Model 3 we added the 'standard' control variables that may influence firm performance. From Table 2 it can be seen that once we control for firm size, age, sector and innovativeness and for the skills of the entrepreneur and labour force only the extent to which a firm's sales 
were to government had a significant impact on sales growth during the year. This means that having access to government contracts and providing government with goods and services is a clear advantage for firm performance in Lebanon, even when we control for all the standard determinants of firm performance. Hence, even having more skilled workers or managers, or being more innovative and investing in an own, or shared, power generator will not make up for the lack of supplying government.

A difference between Model 3 and Model 4 is that in the latter we included a dummy variable if the firm is a family firm or not. Family ownership of firms is ubiquitous in the Middle East and Lebanon, and a growing literature is emerging on the role and impact of family firms and their internal and external networks (see e.g. Fahed-Sreih et al., 2010; Welsh and Raven, 2006). Through such networks, family firms may have some advantages in terms of dealing with the governance problems of the political hybrid order in Lebanon. The results in Model 4 seems to bear this out, since it shows that once we control for a firm being a family firm, the extent of paying bribes to government officials are not anymore associated with negative sales growth (the coefficient on bribes becomes insignificant). Somehow, the family networks of firms in Lebanon seem to overcome the institutional gaps that require bribes and result in poor performance for non-family firms.

The key interpretation from the analyses in Tables 2 and 3 is that family firms who engage in bribery to ensure government contracts seem to alleviate electricity problems and perform best in the hybrid political environment of Lebanon.

\subsubsection{Determinants of Investment in Own Power Generators}

In the previous section we reported that in Lebanon, firms who had better access and use of their own, or a shared, power generator, were able to achieve higher sales growth, ceteris paribus. However once we controlled for other factors, particularly firms' networks and connections, electricity problems ceased to impact on firm performance. Thus, it seems, firms may face a decision whether to invest in their own power generators, or, alternatively, a form of political connections to deal with electricity constraints. In this section we investigate this hypothesis further by regression analysis. We run a probit regression of the discrete decision to 
invest in an own power generator (yes $=1 ;$ no $=0$ ) on key explanatory variables such as the number of power outages and the extent to which political instability is a severe or major constraint, as well as a number of control variables, broadly similar to Alby et al. (2013) .

The probit results are contained in Table 4. 
Table 4: Probit estimation of the determinants of Lebanese firms' decisions to invest in an own power generator

\begin{tabular}{|c|c|c|}
\hline Variable & Model 1 & Model 2 \\
\hline Constant & $\begin{array}{l}1.29 \\
(3.34)^{* * *}\end{array}$ & $\begin{array}{l}2.10 \\
(2.44)^{*}\end{array}$ \\
\hline \multicolumn{3}{|l|}{ Independent } \\
\hline Political & $\begin{array}{l}-0.17 \\
(-0.45)\end{array}$ & $\begin{array}{l}-0.83 \\
(-1.15)\end{array}$ \\
\hline Electricity & $\begin{array}{l}0.45 \\
(1.78)^{*}\end{array}$ & $\begin{array}{l}0.54 \\
(1.63)\end{array}$ \\
\hline Outages & $\begin{array}{l}0.00 \\
(0.89) \\
\end{array}$ & $\begin{array}{l}0.002 \\
(1.33)\end{array}$ \\
\hline \multicolumn{3}{|l|}{ Controls } \\
\hline Smallfirm & & $\begin{array}{l}-1.05 \\
(-1.96)^{*}\end{array}$ \\
\hline Female & & $\begin{array}{l}-0.62 \\
(-1.85)^{*}\end{array}$ \\
\hline Sector: Manufacturing & & $\begin{array}{l}0.88 \\
(1.97)^{*}\end{array}$ \\
\hline Network & & $\begin{array}{l}0.02 \\
(0.06)\end{array}$ \\
\hline Sales to Government & & $\begin{array}{l}-0.001 \\
(-0.20)\end{array}$ \\
\hline Bribes & & $\begin{array}{l}-0.37 \\
(-1.11)\end{array}$ \\
\hline Finance & & $\begin{array}{l}0.008 \\
(1.75)^{*}\end{array}$ \\
\hline Family & & $\begin{array}{l}0.63 \\
(1.67)^{*}\end{array}$ \\
\hline \multicolumn{3}{|l|}{ Diagnostics } \\
\hline $\mathrm{N}$ & 356 & 307 \\
\hline$\chi^{2}(3) ; \chi 2(11)$ & 4.25 & $27.31^{*}$ \\
\hline Pseudo $\mathrm{R}^{2}$ & 0.03 & 0.25 \\
\hline
\end{tabular}

The results in Table 4 indicate that in the simple model (model 1) only the extent to which firms have reported electricity as a severe or major constraint has a positive impact on the probability of a firm investing in an own generator. However, when we control for a set of standard firm and industry level variables, we find that the number of power outages, whether firms report electricity to be a severe or major constraint, and whether firms report political instability to be a severe or major constraint, are not significant determinants of a firm's decision to invest in an own generator. Only firm and industry level factors influence this decision significantly. Thus we can see from Table 4 that small firms and female-owned firms have less probability of investing in an own power generator and that firms with access to finance (as measured by being able to buy inputs on credit) and being in the manufacturing 
sector have a higher probability. Family-owned firms also were more likely to invest in an own generator than non-family owned firms. Hence, in sum, we can conclude that larger, maleowned firms that are within a family, and with access to credit, are more likely to invest in their own generator.

\section{Discussion and Interpretation}

Having established the regression results for our hypotheses based on the WBES data, we will shed some more thorough light on them based on our in-depth interview data.

At first glance, it seems that the hybrid political order in Lebanon has resulted in an environment where poor public provision of a utility like electricity has made place for private initiatives such as generators. One interpretation is that, due to the fragmented governance structure in the country and the traditional potency of entrepreneurship in Lebanon official central control over these private solutions to electricity could not be established. From our interviews with local entrepreneurship experts, however, we conclude that the distinction between public and private is highly misleading here, due to the oligopolistic nature of the sector and the clientelist handing out of contracts (where even privatization does not lead to competition and lower prices). ${ }^{6}$ This goes for the EDL electricity as well as the generators that are indeed private, but not competitive as each neighborhood is allocated to one generator provider that has the backing from politicians and thus does not face competition and can set the prices it wants - at least for smaller firms (Mohsen, 2012). So, while there is indeed no formal, central control, neither are 'private' alternatives free from informal, local political control - an essential that reflects the nature of the hybrid political order. Hence the issue with the relation between electricity provision and political hybridity is not so much about bribery, nor about the individual firm-state connection, but about the more structural oligopolistic organization of the electricity sector that results in high prices.

\footnotetext{
${ }^{6}$ This corresponds with findings by Hasbani (2011), Leenders (2012), Verdeil (2009) and Abdelnour (2003).
} 
The experts we interviewed consider the clientelist and oligopolistic nature of the utility sector, which is a result of the politically hybrid regime, as the fundamental reason for the poor state of electricity supply. The Lebanese sectarian quota system effectively working as an official mechanism to 'divide the pie' of state jobs among sectarian communities through a clientelist award system, was often mentioned as the core problem. Observers noted that 'politicians put their people in the administration and now even the public companies are divided. ${ }^{7} \mathrm{~A}$ civil servant explained that 'there is a paradox in that the economy is business-driven, while key facilitating infrastructural sectors are government owned. ${ }^{8}$ The World Bank (2008:4) confirms that electricity subsidies have reached 39 per cent of total government spending between 1997 and 2006. Yet the overwhelming perception seems to be that while the government, as a state institution, might be losing money on the electricity file, politicians, as private economic actors, are carefully scooping up the same money through their affiliated companies and contacts. ${ }^{9}$

Our interviewees stressed this 'entanglement' of the public and private sectors as a core aspect of the hybrid political order that can help understand the functioning of Lebanon's utility sectors. ${ }^{10} \mathrm{~A}$ leading analyst concluded that while the private sector claims it wants to remain out of politics, and therefore refuses to lobby for better governance regulation, this is in fact 'preposterous,' as they are all 'entangled'. ${ }^{11}$ Such observations seem more than justified in light of existing research into the workings of patronage networks in the public and private sectors in Lebanon, where several major families or clans dominate business as well as politics (Leenders

\footnotetext{
${ }^{7}$ Authors' interview with civil society watchdog, Beirut - 4 July 2012.

${ }^{8}$ Authors' interview with ministerial representative, Beirut - 20 June 2012.

${ }^{9}$ Authors' interview real estate expert, Beirut - 27 June 2012.

${ }^{10}$ Some scholars conversely stress that relations between private sector, public sector and civil society differ per sector and that politicization only occurs when there is significant money to be made - arguably including the electricity sector. Moreover, some respondents acknowledge that while 'the big businesses related to infrastructures and utilities are all indeed connected in one way or another to politicians, if you go one notch beyond that, things are not as corrupt as you might think. You can be, for instance, a successful Mercedes Benz dealer because you're a good businessman, regardless of political connections' (authors' interview entrepreneurship scholar, Beirut - 25 June 2012). This reflects Mehzer et al.'s (2008:44) finding that although political affiliations are very common sources of advantage in Lebanon, the advantages of such connections ranked only fifth among the manager attributes that influence success. Some experts even stress the fact that entrepreneurs (from former prime-minister Hariri to current Prime Minister Miqati) are leading politicians in Lebanon point to a merit-based and technical conception of governance, a 'businessization' of politics rather than politicization of business (authors' interview entrepreneurship education expert, Beirut - 25 June 2012).

${ }^{11}$ Authors' interview with political economist, Beirut - 19 July 2012.
} 
2004, 2012). This is largely due to Lebanon's public contracting system that is extremely vague. The Lebanese Transparency Association (LTA) (2011:85) euphemistically states that 'very limited information exists around contracting and there is no information available about the size of the procurement market'. Clearly, transparency is an issue. In practice, public contracting and procurement is subject to patronage and clientelism, 'whereby all political leaders take advantage of their position to promote the interests of their own communities' (LTA, 2011:87). Many of the experts we consulted seem to agree with Kaplan (2009:7) that in Lebanon, 'successful entrepreneurs are not those with the best ideas, but those with the best ties to ruling elites'. Spokespersons of a civil society watchdog declared that if you know how to bribe well, you can do well' and signal 'immense conflicts of interest between politics and business'. ${ }^{12} \mathrm{~A}$ diplomat described the Lebanese entrepreneurship climate as a mix between ' $19^{\text {th }}$ century American brigand capitalism and Soviet steering'. ${ }^{13}$ Lebanese political analysts confirm that the political class is 'embedded in the private sector' as 'most businessmen are former state officials and most politicians have some businesses' ${ }^{14}$

Based on our qualitative interviews, we thus propose to see the quantitative regression results in light of the overarching 'public-private entanglement' structurally referred to by our interviewees. The fact that hybridity is reported to affect entrepreneurship mainly through instability when it comes to larger firms and predominantly through access to electricity for smaller firms reflects that larger firms, due to their visibility, are more likely to encounter direct political interference. For the same reasons, however, they are also more able, and thus likely, to invest in connections to with political elites in order to overcome electricity constraints. Political instability, i.e. changes in the political order and the relative might of specific factions or communities and resultant policy fluctuation, might therefore be more detrimental to their businesses than they are for smaller firms. On top of that, larger firms may also be able to overcome electricity and finance constraints from their own resources, whereas small firms cannot. Small firms, by being less visible or less obviously endowed, may avoid political scrutiny

\footnotetext{
${ }^{12}$ Authors' interview with civil society watchdog, Beirut - 4 July 2012.

${ }^{13}$ Authors' interview with diplomat, Beirut - 19 July 2012.

${ }^{14}$ Authors' interview with political economist, Beirut - 19 July 2012.
} 
(often a reason for firms remaining small in the first place), but simultaneously also the access to elite networks that can function as a resource to deal with entrepreneurial constraints. We may conclude from this that larger firms have to face direct manifestations of hybridity (political instability) whereas smaller firms face the indirect - downstream - manifestations of hybridity (sunken costs for utilities).

Entrepreneurs' responses to electricity constraints, illustrate the significance of the blurred lines between the public and private realms even more poignantly. Firstly, while bribing is an important strategy to alleviate electricity problems, it does not so much concern direct bribing on the consumption level of the electricity sector, but rather bribing for contracts, an informal form of bridging - or distorting - the public and the private. This, secondly, makes supplying to government an unsurpassed strategy to mitigate electricity constraints for entrepreneurs. Experts we interviewed consistently claimed that being on the receiving end of the distribution of contracts and jobs in the electricity sector is rewarding (see also Verdeil, 2009; Hasbani, 2011; Sulahian, 2004), which further cements the impression that it is private actors' inlays into public sector institutions that to a large extent determines their ability to deal with electricity problems that follow from the country's hybrid political order. The utility of family connections for entrepreneurs to deal with electricity challenges, thirdly, might further suggest the importance of the overlap between private business networks and public decision-making networks in understanding the relations between entrepreneurship and political order. The absence of any indication that political order indicators affect entrepreneurs' generator ownership, fourthly and finally, might - albeit in a paradoxical way - only further underline the conclusion that it is the extent to which private actors can influence (or even become) public actors that explains their ability to deal with the electricity problems stemming from a hybrid political order context. Our finding that generator investment is only significantly affected by business level indicators, namely, can be seen to show that while businesses get a generator when they can, this does not relieve them from their needs to establish bridges - either through bribing, supplying to government or family networks - between their private enterprises and the public institutions shaping the electricity sector. They can, apparently, partially buy off such needs by a generator, but they cannot entirely circumvent the 
oligopolistic, limited access nature of the governance of the sector through a generator, which further illustrates the comprehensiveness of the oligopolistic logic in the Lebanese electricity sector.

The oligopolistic governance of the Lebanese electricity sector that generates such serious problems for Lebanese entrepreneurs is widely recognized to stem from the country's hybrid political order. Entrepreneurs' responses to the electricity problems presented to them, however, equally reflect Lebanon's hybrid political order and entrepreneurs' bribing, supplying to government and utilization of family connections confirm and even reinforce the oligopolistic logic of the hybrid political order. It thus seems that, ultimately, Lebanese entrepreneurs do not so much challenge the hybridity that is one of their key constraints, but rather seek to utilize it to navigate these same constraints - fighting fire with fire.

\section{Concluding Remarks}

In this paper we provided findings on how entrepreneurial decisions and firm performance are affected in a hybrid political order by studying the case of entrepreneurs' access to electricity in Lebanon. Lebanon is a prime example of a hybrid political order where economic control is divided following an inter-sectarian power-sharing formula that results in endemic patronage and clientelism and a highly oligopolistic market structure. In such a hybrid political order, one expects a priori that successful entrepreneurs are not those with the best ideas or economic resources, but those with the best political connections and institutional networks. As such, entrepreneurial success may be a function of their ties to the elite and the impact of lack of access to electricity, one of the major shortcomings in most developing countries, may affect entrepreneurs differently depending on the extent of these ties.

In light of these considerations we put forward two hypotheses in this paper: namely that unreliable electricity provision will have a negative impact on firm performance in Lebanon and that entrepreneurs who are able to invest in their own generators and and/or influence political elites may experience electricity supply, and also the political instability generated by the hybrid political order, to be less serious business obstacles. Using firm-level data from the WBES 
of Lebanon and augmenting this with our own qualitative interviews with entrepreneurship experts in Lebanon we could not reject these hypotheses. Specifically, we found that (i) family firms whose entrepreneurs engage in bribery (to access government contracts) alleviate electricity problems in the process and ultimately perform better; and that (ii) entrepreneurs who are male, and with access to credit, are more likely to invest in an own electricity generator than other firms.

These results reflect the fact that a hybrid political order imposes a 'tax' on entrepreneurship through channelling entrepreneurial talent into bribery and lobbying; through reinforcing male and family-owned dominance in business; and by skewing investment decisions - for instance into using access to finance to invest in an own generator, due to the difficulty of accessing publicly provided electricity without access to government contracts.

In the former regard our results are consistent with the entrepreneurship literature wherein a lack of strong institutions is seen as leading to sub-optimal entrepreneurial performance and the increase in non-productive and even destructive forms of entrepreneurship (Baumol, 1990). In the latter regard, our results add to that of for instance Alby et al. (2013) who estimated the determinants of the decision of a firm to invest in an own electricity generator, but did not investigate to what extent a country's political order influenced this decision. Our results show that the political order matters for entrepreneurship and that, in Lebanon, institutional reforms that will result in broader and more equal access to public electricity could make a positive contribution to entrepreneurial performance. 


\section{References}

Abdelnour, Z.K. (2003). 'The Corruption behind Lebanon's Electricity Crisis', ME Forum Online, $5,8-9$.

Ahmed, Z.U. and Julian C.C. (2012). 'International Entrepreneurship in Lebanon' Global Business Review 13:1:25-38.

Alby, P., Dethier, J-J. and Straub, S. (2013). 'Firms Operating under Electricity Constraints in Developing Countries', World Bank Economic Review, 27 (1): 109-132

Bardhan, P. (2004). 'Governance issues in delivery of public services', Journal of African Economies 13(1): 167-182.

Baumol, W.J. (1990). 'Entrepreneurship: Productive, Unproductive and Destructive', The Journal of Political Economy 98(5): 893-921.

Berry, C., Forder, A., Sultan, S. and Moreno-Torres, M. (2004). 'Approaches to improving the delivery of social services in difficult environments', PRDE Working Paper 3, UK Department for International Development.

Boege, V, A Brown and Clements, K. (2009). Hybrid Political Orders, Not Fragile States. Peace Review: A Journal of Social Justice, 21, 13-21.

Briscoe, I. (2009). 'Chasing the Tigers. Can Fragile States Copy the Asian Miracle', Conference Report Fundacíon par alas Relaciones Internacionales y el Díalogo Exterior (FRIDE) Seminar in Madrid, 6-7 October 2008.

Brück, T., Naudé, W.A. and Verwimp, P. (2013). 'Business under Fire: Entrepreneurship and Violent Conflict in Developing Countries', Journal of Conflict Resolution, February Vol. 57: 3-19.

Cammett, M and Issar, S.S. (2010). 'Bricks and Mortar Clientelism: Sectarianism and the Logics of Welfare Allocation in Lebanon', World Politics, 62, 3, 381-421.

Coad, A., Segarra, A. and Teruel, M. (2013). 'Like Milk or Wine: Does Firm Performance Improve with Age?', Structural Change and Economic Dynamics, 24 : 173-189.

Coad, A. and Tamvada, J. (2012). 'Firm Growth and Barriers to Growth amongst Small Firms in India', Small Business Economics, 39 (2): 383-400. 
Dagher, L and Ruble, I. (2011). ‘Modeling Lebanon's electricity sector: Alternative scenarios and their implications', Energy, 36, 4315-4326.

Dagher, L and Yacoubian. T. (2012). 'The causal relationship between energy consumption and economic growth in Lebanon', Energy Policy, 50, 759-801.

Dollar, D., Hallward-Driemeier, M. and Mengistae, T. (2005). 'Investment Climate and Firm Performance in Developing Economies', Economic Development and Cultural Change, 54: 1-31. Fahed-Sreih, J., Pistrui, D., Huang, W.A, and Welsh, H.P. (2010). 'Family and Cultural Factors Impacting on Entrepreneurship in War Time Lebanon', International Journal of Entrepreneurship and Innovation Management, 12 (1): 35-51.

Faour, M. (2007). 'Religion, Demography and Politics in Lebanon', Middle Eastern Studies, 43, 6, 909-921.

Foster, V. and Steinbuks, J. (2009). 'Paying the Price for Unreliable Power Supplies: In-House Generation of Electricity by Firms in Africa', Policy Research Working Paper no. 4913, Washington DC: The World Bank.

Gollin, D. (2008). 'Nobody's business but my own: Self-employment and small enterprise in economic development', Journal of Monetary Economics, 55 (2): 219-233

Guglielmetti, C (2010). 'Measuring the Business Environment for Entrepreneurship in Fragile States', UNU-Wider working paper 2010/14. Helsinki: Finland.

Haddad, S. (2002). 'Cultural Diversity and Sectarian Attitudes in Postwar Lebanon', Journal for Ethnic and Migration Studies, 28, 2, 291-306.

Hagmann, T. and Hoehne, M.V. (2009). 'Failures of the State Failure Debate: Evidence from the Somali Territories', Journal of International Development 21:42-57.

Hamzeh, N. (2001). 'Clientalism, Lebanon: Roots and Trends', Middle Eastern Studies, 37, 3, 167-178.

Hasbani, K.U. (2011). 'Electricity Sector Reform in Lebanon: Political Consensus in Waiting', Working Paper for the Stanford Center on Democracy, Development, and The Rule of Law.

Kanaan, N.M. (2011). 'Energy-GDP Nexus: The Case of Lebanon. A Time Series Approach'. MA Thesis AUB. 
Kaplan, S. (2009). 'Enhancing Resilience in Fragile States'. Paper prepared for the conference on Moving Towards the European Report on Development 2009, organised by the European Report on Development. Florence, Italy - 21-23 June.

Kenyon, T. and Naoi. M. (2010). 'Policy Uncertainty in Hybrid Regimes: Evidence from FirmLevel Surveys', Comparative Political Studies 43:4:486-510.

Leenders, R. (2004). 'Nobody Having too Much to Answer for: Laissez-Faire, Networks and Postwar Reconstruction in Lebanon' (In Heydemann, S. ed. Networks of Privilege in the Middle East: The Politics of Economic Reform. London: Palgrave/Macmillan).

Leenders, R (2012). Spoils of Truce: Corruption and State-building in Postwar Lebanon. Ithaca: Cornell University Press.

Leibenstein, H. (1968). 'Entrepreneurship and Development', American Economic Review, 58 (2): $72-83$.

LCPS (2011). Entering a Grey Area: Lebanon's Economic Challenges in the Arab Spring. Beirut: LCPS.

LTA (2011). National Integrity System Study Lebanon 2011. Beirut: LTA.

Lund. (2011). Engaging Fragile States. An International Policy Primer. Lessons from Recent Research and Practice. Woodrow Wilson International Center for Scholars.

Mehzer, T., R. El-Saouda, W. Nasrallah and M. Al-Ajam (2008). 'Entrepreneurship in Lebanon: A model for success and failures.' Journal of Arab Culture, Management and Sustainable Development, 1(1): 34-52.

Mohsen, A. (2012). Lebanon's Electricity Mafia. Al Akhbar English Website.

Naudé, W.A. (2010a). 'Entrepreneurship, Developing Countries and Development Economics: New Approaches and Insights', Small Business Economics Journal, 34 (1): 1-12.

Naudé, W.A. (2010b). 'Promoting Entrepreneurship in Developing Countries: Policy Challenges', UNU Policy Brief, no. 4, 2010. Tokyo: United Nations University.

Naudé, W, A.U. Santos-Paulino and M. McGillivray (eds.). 2011. Fragile States. Costs, Causes, and Responses. Oxford: Oxford University Press. 
Naudé, W.A. (2013). 'Entrepreneurship and Economic Development: Theory, Evidence and Policy" (In Currie-Alder, B.; R. Kanbur, D. Malone and R. Medhora (eds). International Development: Ideas, Experience, and Prospects. Oxford: Oxford University Press. Chapter 17).

North, D.C., Wallis, J.J., Webb, S.B. and Weingast, B.R. (2007). 'Limited Access Orders in the Developing World: A New Approach to the Problems of Development', Policy Research Working Paper 4359, Washington DC: The World Bank.

North, D.C., Wallis, J.J., and Weingast, B.R. (2009). Violence and Social Orders: A Conceptual Framework for Interpreting Recorded Human History. Cambridge: Cambridge University Press.

OECD (2008). Service Delivery in Fragile Situations. Key concepts, findings and lessons. Journal of Development 9(3): 3-54.

Quatraro, F. and Vivarelli, M. (2013). 'Drivers of Entrepreneurship and Post-Entry Performance of Newborn Firms in Developing Countries', IZA Discussion Paper no. 7436, Bonn: Institute for the Study of Labor.

Reinikka, R. and Svensson, J. (2002). 'Coping with Poor Public Capital', Journal of Development Economics, 69: 51-69.

Schmotz, A. (2010). 'The Dynamics of Hybrid Regimes: Surviving Institutional Tension'. Berlin Graduate School of Social Sciences.

Sørensen, J.B. and Chang, P.M.Y. (2006). 'Determinants of Successful Entrepreneurship: A Review of the Recent Literature'. Report prepared for the Ewing Marion Kauffman Foundation. Stel, N.M. (2012). Entrepreneurship and innovation in a hybrid political order: The case of Lebanon. UNU-MERIT working Paper 78 . United Nations University [http://www.merit.unu.edu/publications/wppdf/2012/wp2012-078.pdf]

Stel, N.M. (2013). 'Entrepreneurs in the Dark: The Impact of Fragile and Hybrid Governance on Lebanese Entrepreneurship - A Case Study of the Electricity Sector', Journal of Developmental Entrepreneurship, 18 (3): 1-17.

Sulahian, R.H. (2004). Assessing the Lebanese Electricity Privatization Law'. MA thesis AUB. 
Vaux, T. and Visman, E. (2005). 'Service delivery in countries emerging from conflict', Report for UK Department for International Development, Centre for International Cooperation and Security, Department of Peace Studies, Bradford University.

Verdeil, E. (2009). Électricité et Territoires: Un Régard Sur Crise Libanaise. Revue Tiers Monde, $198,421-436$.

WBES (2009). World Bank Enterprise Surveys. Lebanon.

WEF (2011). Accelerating Entrepreneurship in the Arab World. Beirut: WEF.

Welsh, D.H.B. and Raven, P. (2006). 'Family Business in the Middle East: An Exploratory Study of Retail Management in Kuwait and Lebanon', Family Business Review, 19 (1): 29-48.

World Bank (2008). Republic of Lebanon. Electricity Sector Public Expenditure Review. Washington: WB.

Ziadeh, H. (2006). Sectarianism and Intercommunal Nation-Building in Lebanon. London: Hurst. 